\title{
Preparation of odour removal catalysts with self-regeneration capability
}

\author{
Yongxiang Zhao $^{1} \cdot$ Lili Zhao $^{1} \cdot$ Yu Huang ${ }^{2} \cdot$ Haoyi Chen $^{2} \cdot$ Tiancun Xiao ${ }^{1,2,3}$
}

Received: 29 February 2016/ Accepted: 23 May 2016/Published online: 9 June 2016

(c) The Author(s) 2016. This article is published with open access at Springerlink.com

\begin{abstract}
Odours remain at the top of air pollution complaints both indoor and outdoor, which can come from sewage, rotten food, and human digestions. Activated carbon has been used to absorb the odour materials, but its physical absorption can easily be saturated and could be a potential pollution source when less odour compounds exist in the surrounding environment. Here, for the first time, we have developed an activated carbon-alumina composite-supported $\mathrm{ZnCu}$ bimetallic metal oxide catalyst, which not only has very high capacity to absorb the strong smell sulfide, but also can convert sulfide into sulfur by the oxygen in air and the organic sulfur into sulfone, which removes the odour material in a chemical way and also endows the self-regeneration ability for the sorbent, leading to a longer and more efficient way to control odour in air. The $\mathrm{ZnCu}$ catalyst which contains $50 \%$ of active carbon in the support has the highest sulfur capacity. The preparation parameters, such as calcination temperature, composition of the active components, and the test conditions, have a significant effect on the odour removal capability, and the conversion over the catalyst. The main structure of the bimetallic oxide catalysts does not change even after halfyear industrial site use, which completely converts sulfur
\end{abstract}

Tiancun Xiao

xiao.tiancun@chem.ox.ac.uk

1 School of Chemistry and Chemical Engineering, Shanxi University, Taiyuan 030006, Shanxi, People's Republic of China

2 Guangzhou Boxenergytech Ltd, No. 3 Juquan Road, Guangzhou Science City, Guangzhou, Guangdong, People's Republic of China

3 Inorganic Chemistry Laboratory, University of Oxford, South Parks Road, Oxford OX1 3QR, UK into sulfur powder and also convert $\mathrm{CO}$ into $\mathrm{CO}_{2}$. The surface morphology changes, while the main crystalline structure remains, which showed the self-regenerability of the catalyst.

Keywords Odour removal - Composite support - Catalyst . Self-regeneration $\cdot$ Sulfur-containing compounds

\section{Introduction}

Odour problems arising from sewage, furniture, or human and pet's activities have been continuing to grow in significance over recent years. [1-6]. Common and strong odorous compounds often include reduced sulfur compounds which may come from sewage, water, or toilets $[7,8]$. In refinery or petrochemical plants, sulfur-containing compounds have been identified as the predominant odorants in a wide range of odour emissions in heavy oil coking, sulfur recovery unit, which has caused serious environmental problem [6]. Hydrogen sulfide $\left(\mathrm{H}_{2} \mathrm{~S}\right)$ is produced as a by-product of fart and also the decomposition of sulfur-containing organic constituents of manure. These sulfur-containing odour materials not only corrode the infrastructure, but also caused ill or sick to the people around. In fact, among the odour substances, $\mathrm{H}_{2} \mathrm{~S}$ is often the main and most often seen chemical causing the uncomfortable feeling and needs control first [5, 9-11]. The other organic sulfur compounds, such as thiophene, carbonyl sulfide, are normally much less than $\mathrm{H}_{2} \mathrm{~S}$, but also possess a much stronger smell $[5,8,12]$.

A very often used method for sulfur-containing compound removal is biological process. However, biological processes take long time to remove odours and also produce organic wastes as by-product that needs to be 
disposed of eventually [9, 13]. In addition, biological method is not applicable to the open environment, which changes so frequently and temperatures are not stable. There have been lots of interests in developing new materials for physical removal or chemical removal of sulfur-containing odours. Huang and Khan et al. reviewed the adsorptive removal of toxic/hazardous components (mainly from fuel, wastewater, and air) by virgin or modified metal-organic framework (MOF) materials $[14,15]$. They discussed the possible interactions between sulfurcontaining odour compounds and active MOF adsorption sites. However, MOF only absorbs the sulfur-containing odour substances, but can not convert them, which behave the similar mechanism like active carbon. Kim et al. studied the removal of sulfur-containing odorants from natural gas using the sorption method, they prepared $\mathrm{CuO} /$ $\mathrm{ZnO} / \mathrm{Al}_{2} \mathrm{O}_{3}$ sorbents using the co-precipitation/aging method. A reduced sorbent, namely $\mathrm{Cu} / \mathrm{ZnO} / \mathrm{Al}_{2} \mathrm{O}_{3}$, has a sorption capacity of $0.5 \mathrm{mmol} / \mathrm{g}$ at $250{ }^{\circ} \mathrm{C}$ when the sodium content is kept below $0.027 \mathrm{wt} \%$. However, for atmospheric air purification, where oxygen is present, the sorbent is not suitable [16]. For odour adsorption, Y-type zeolites modified with $\mathrm{Cu}, \mathrm{Ni}$, and $\mathrm{Mn}$, as well as mesoporous hexagonally ordered silicates and niobosilicates of MCM-41 type with gold dispersed as an active component were studied too, especially for $\mathrm{Di}-\mathrm{Bu}$ sulfide and $\mathrm{Bu}$ amine, but no $\mathrm{H}_{2} \mathrm{~S}$-containing gas was tested [17].

Overviewing the previous literatures show that there have been quite a lot of studies on the removal of odour sulfur compound using the adsorption method [18, 19]. However, so far, very few publications have been reported on the $\mathrm{H}_{2} \mathrm{~S}$ and the organic sulfur chemical conversion to odourless sulfur and also, the sorbent can experience selfregeneration during the application. Especially, in the open air environment for long-term applications, such as in waste water treatment plant or sludge disposal, where there have been lots of surface sulfur odour sources, the sorbent could be embedded into the construction materials as long its functions would be sustained, which does not need regular changes. This would be a big challenge for the odour removal catalyst development. In this work, we have developed a self-regenerable catalyst types sorbent, which can effectively convert $\mathrm{H}_{2} \mathrm{~S}$ and $\mathrm{COS}$ into sulfur powder and also convert $\mathrm{CO}$ into $\mathrm{CO}_{2}$, thus removing the odour in an actively chemical ways.

\section{Experimental}

\section{Preparation of the sulfur removal catalyst}

The zinc nitrate $\left[\mathrm{Zn}\left(\mathrm{NO}_{3}\right)_{2} \cdot 6 \mathrm{H}_{2} \mathrm{O}\right.$, Tianjin Kemiou Chemical Reagent $\mathrm{Co}]$ and copper nitrate $\left[\mathrm{Cu}\left(\mathrm{NO}_{3}\right)_{2} \cdot 3 \mathrm{H}_{2} \mathrm{O}\right.$,
Tianjin Kemiou Chemical Reagent Co] were dissolved in water at the $\mathrm{ZnO}: \mathrm{CuO}$ ratio of 1:2, and the aqueous mixture solution is then soaked into the mixture of beomite $\left(\mathrm{Al}_{2-}\right.$ $\mathrm{O}_{3} \cdot \mathrm{H}_{2} \mathrm{O}$, Tianjin Kemiou Chemical Agent) and active carbon with critic acid added to the mixture at the mole ratio of $\mathrm{Zn}: \mathrm{Cu}:(\mathrm{Al}+\mathrm{C}):$ critic acid $=1: 2: 18: 0.05$. The addition of citric acid is to increase the dispersion of the transition metal $[20,21]$. The mixture was stirred for $4 \mathrm{~h}$ under ambient conditions, naturally dried until it becomes pasta, and then heated at $120{ }^{\circ} \mathrm{C}$ for $24 \mathrm{~h}$ to get a powder mixture, followed by calcinations at $300{ }^{\circ} \mathrm{C}$ for $8 \mathrm{~h}$ to get a $\mathrm{ZnCuO}_{x} / \mathrm{Al}_{2} \mathrm{O}_{3}-\mathrm{C}$ mixture powder.

To increase the surface area and change the pore structure of the sorbent, active carbon (chemical grade, Chemical Agent Co Ltd, China National Pharm Group) was introduced to the beomite at various contents through adding water, sodium hydroxide $(\mathrm{NaOH}$, chemical grade, Chemical Agent Co Ltd, China National Pharm Group), mixing and extrudation into cylinder shape. The extrudate ( $3.5 \mathrm{~mm}$ in diameter and $5-10 \mathrm{~mm}$ long) is calcined at various temperatures for $3 \mathrm{~h}$ in static air to give the finished odour converting catalysts.

The reason for adding activated carbon is to increase the absorption capacity for the organic sulfur which is more affinitive to neutral hydrophobic surface. This is through the combination of the high surface area active carbon support with the alumina support through the water-milling-paste and calcination method.

The metal content in the final calcined sorbent was analyzed using X-ray fluorescence (XRF, MAXXI Eco), and the metal contents in the sulfur removal catalyst were $\mathrm{ZnO} 8.5$ and $\mathrm{CuO} 15.6$ wt\%.

\section{Activity test of the prepared catalysts}

\section{The breakthrough of sulfur capacity of the catalysts}

The sulfur capacity at breakthrough point refers to the total sulfur pickup per gram of the sorbent when the exit $\mathrm{H}_{2} \mathrm{~S}$ in the gas stream reaches a specific limit. The sulfur capacity (Sc) can be calculated as follows:

$\mathrm{Sc}=M_{\mathrm{H}_{2} \mathrm{~S}} / M_{\mathrm{Cat}} \times 100 \%$,

where $M_{\mathrm{H}_{2} \mathrm{~S}}$ is the total sulfur absorbed or deposited over the catalyst, and $M_{\text {cat }}$ is the total weight of the catalyst used.

The specific limit in the exit gas in our test was set at $0.1 \mathrm{ppm}$ for $\mathrm{H}_{2} \mathrm{~S}$ and $1 \mathrm{ppb}$ for the other sulfur-containing odour substances.

The catalyst test apparatus is shown in Fig. 1. In the labscale test, the inlet gas can be switched between pure $\mathrm{N}_{2}$ and air with all containing $\mathrm{H}_{2} \mathrm{~S}$ of $1000 \mathrm{ppm}$, so as to test 
Fig. $1 \mathrm{H}_{2} \mathrm{~S}$ removal sorbent test system at ambient conditions

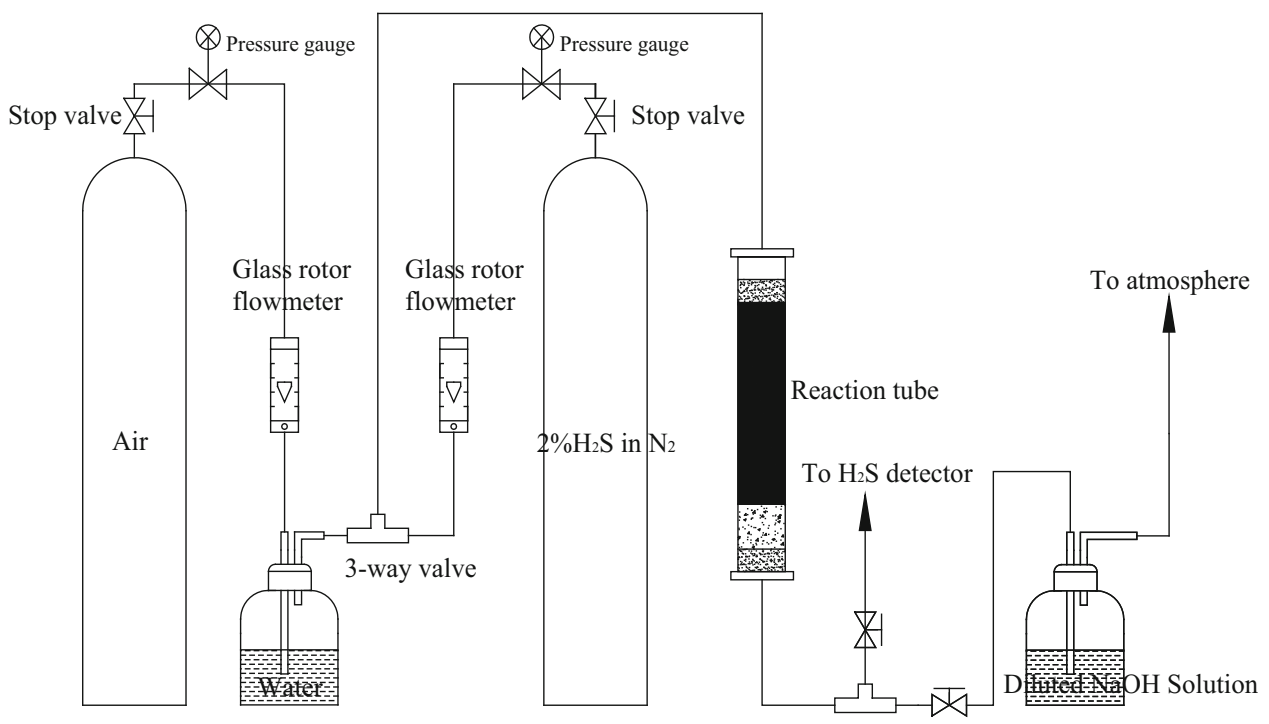

the effect of gas composition on the sulfur capacity. The use of high concentration of $\mathrm{H}_{2} \mathrm{~S}$ in the gas stream is to accelerate the test. Each time, $1.15 \mathrm{~g}$ of catalyst is loaded into (1) $6.3 \mathrm{~mm}$ glass tube plugged with glass wool at the two ends. The exit gas was analyzed using an on-line GC, and then passes through a $\mathrm{NaOH}$ wash bottle, before it is emitted to air.

The sulfur was analyzed using a Yimen GC A90 equipped with the FPD sulfur analyzer system using nitrogen as the carrier gas at pressure of $0.4 \mathrm{MPa}$, hydrogen at $0.35 \mathrm{MPa}$ for flame, the FPD detector, and vaporization temperatures were kept at $250{ }^{\circ} \mathrm{C}, \mathrm{H}_{2} \mathrm{~S}$ about $1000 \mathrm{ppm}$.

\section{Characterization of the sulfur removal catalyst}

\section{The strength measurement}

For civil use in various places, the side strength of the catalyst is a very important indicator, as the powdering of the sample might contaminate environment and also make the site messy. We measured the side strength of the extrudate using DL-III intelligent particulate strength meter; each sample was measured for 20 times to get the averaging value of the 18 measurements after excluding the maximum and minimum values.

\section{BET surface area measurement}

The surface area of the prepared samples was analyzed using $\mathrm{N}_{2}$-physisorption analysis with a Micromeritics ASAP-2020 apparatus. Sample (ca. $0.10 \mathrm{~g}$ ) was degassed at $190{ }^{\circ} \mathrm{C}$ for $5 \mathrm{~h}$ before analysis. Specific surface area $\left(S_{\mathrm{BET}}\right)$ was calculated following the multi-point BET procedure.

\section{XRD and SEM-TEM characterization of the catalyst samples}

The contents of $\mathrm{Cu}$ and $\mathrm{Zn}$ in the catalysts were measured using a Varian 710ES inductively coupled plasma-atomic emission spectroscopy (ICP-AES). All the measurements were carried out in triplicate to get the average value. Powder X-ray diffraction (XRD) pattern was recorded with a Bruker D8 Advance diffraction spectrometer with $\mathrm{CuK} \alpha$ radiation $(\lambda=0.154 \mathrm{~nm})$ at a scanning rate of $2.4 \% \mathrm{~min}$ in the $2 \theta$ range of $10^{\circ}-80^{\circ}$.

Transmission electron microscopy (TEM) measurement was carried out using JEM-2100 model TEM with accelerating voltage of $200 \mathrm{kV}$. Sample for TEM was dispersed by sonicator in ethanol followed by deposition of the suspension onto a standard $\mathrm{Cu}$ grid covered with a holey carbon film.

\section{Results and discussion}

\section{The effect of the active carbon addition} on the physical properties and performance of the sulfur conversion catalysts

The performance of odour removal were closely related to the physical properties. In many cases, the sulfur-containing organics are more hydrophobic, while $\mathrm{H}_{2} \mathrm{~S}$ is more hydrophilic; therefore, to fully remove the odour, the support must be porous to have high surface area and should have both hydrophilic and hydrophobic properties. We, therefore, added active carbon to beomite, drop wise adding water to the mixture of active carbon and beomite, while milling and stirring to form a paste, then dried at 
Table 1 Surface area, pore volume, and diameter of the $\mathrm{ZnCuO}_{x} /$ $\mathrm{Al}_{2} \mathrm{O}_{3}-\mathrm{C}$ with various carbon contents

\begin{tabular}{llllll}
\hline $\begin{array}{l}\text { Active carbon content } \\
(\mathrm{wt} \%)\end{array}$ & 30 & 40 & 50 & 60 & 70 \\
\hline Surface area $\left(\mathrm{m}^{2} / \mathrm{g}\right)$ & 111.1 & 158.5 & 291.7 & 325.0 & 373.7 \\
Pore volume $\left(\mathrm{cm}^{3} / \mathrm{g}\right)$ & 0.1085 & 0.1472 & 0.24365 & 0.2712 & 0.3149 \\
Pore diameter $(\mathrm{nm})$ & 3.8 & 3.8 & 3.6 & 3.6 & 3.6 \\
\hline
\end{tabular}

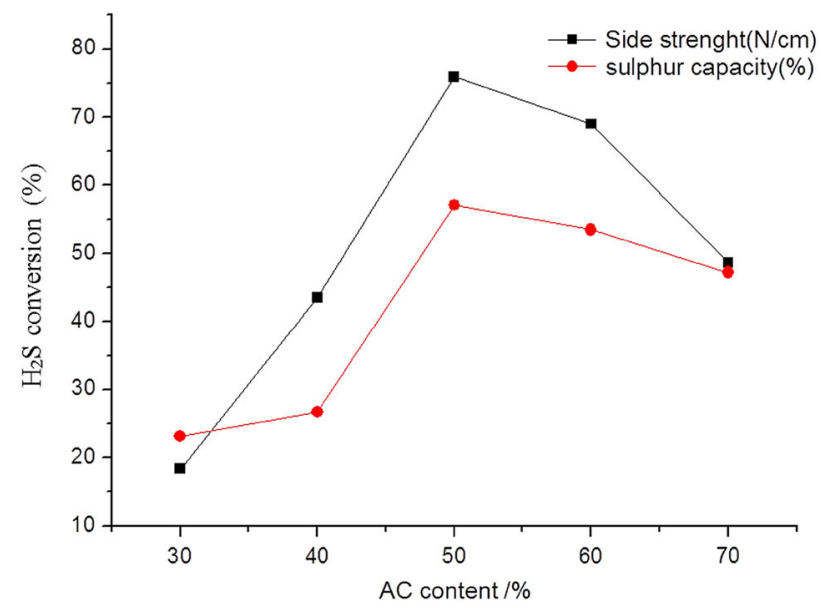

Fig. 2 Change of sulfur removal catalyst with the carbon content in it

$120{ }^{\circ} \mathrm{C}$, and calcined at $260{ }^{\circ} \mathrm{C}$, which we call it millingpaste and calcination method. The calcined support composite is then impregnated with $\mathrm{Zn}$ and $\mathrm{Cu}$ solutions. This kind of composite support preparation was not reported before; the physical properties of the extrudated sorbents are shown in Table 1.

It is interesting to find that the surface areas of the extrudated catalysts increased with the carbon content, therefore, is the pore volume, whose diameters tends to be stable. The increase of surface area and pore volume would favour the odour and organic compounds absorption over the catalyst, which can be converted by the active component. The catalyst with the highest surface area $\left(373.7 \mathrm{~m}^{2} / \mathrm{g}\right)$ has the highest carbon content of $70 \mathrm{wt} \%$.

The catalyst with various carbon contents has been measured for strength and also tested for sulfur removal, and the results are shown in Fig. 2. Clearly, the carbon content has a significant effect on the physical properties and also on the sulfur removal efficiency. Interestingly, the strength increases with the carbon content, therefore, is the sulfur pick-up capacity. It is noted that there is a direct link between the strength and sulfur capacity In fact, in many case, the increase of the strength means a more compact particles, however, in our prepared odour removal catalyst, the sample containing $50 \mathrm{wt} \%$ of carbon has the highest strength and also the highest sulfur capacity, e.g., it can absorb $50 \%$ of its own weight of sulfur. Although the higher carbon content in the catalyst increases the surface area while keeping the copper and zinc content unchanged, but the sample contains $50 \%$ of carbon has high sulfur capacity than the ones with more copper and zinc and also the one with more carbon. This means that there is a synergic effect of the physical properties and the active components in the formulations.

The copper and zinc are, indeed, the active sites, which can absorb sulfur and convert into sulfide initially, but the presence of active carbon increases the surface area and enables more absorptive ability. Therefore, a good sorbent requires high surface area, proper active components content, and dispersion.

\section{The effect of activation temperature on the sulfur removal capacity}

We have shown that the catalyst containing $50 \mathrm{wt} \%$ of active carbon has the highest sulfur pick-up capacity, as shown in Fig. 2. To maximize the performance, the catalyst (after dried at $110{ }^{\circ} \mathrm{C}$ ) has been calcined at various temperatures, and the resultant sorbents have been measured for strength, surface area, and also tested for $\mathrm{H}_{2} \mathrm{~S}$ absorption and conversion. The results are shown in Table 2.

We can see that when calcined from 120 to $240{ }^{\circ} \mathrm{C}$ each for $4 \mathrm{~h}$, the surface area of the catalyst changed from 152.1 to $346.7 \mathrm{~m}^{2} / \mathrm{g}$, while the strength of the extrudate decrease from 91.7 to $40.3 \mathrm{~N} / \mathrm{cm}$ when the calcination temperature increased from 120 to $240{ }^{\circ} \mathrm{C}$. However, the sulfur capacity increases from $20.5 \mathrm{wt} \%$ for the sample calcined at $120{ }^{\circ} \mathrm{C}$ to $53.8 \mathrm{wt} \%$, when the catalyst was calcined at $240{ }^{\circ} \mathrm{C}$. It is noted that the catalysts calcined at $210{ }^{\circ} \mathrm{C}$ is almost the same as the one calcined at $240{ }^{\circ} \mathrm{C}$, although the surface area of the catalyst calcined at $240{ }^{\circ} \mathrm{C}$ has nigger surface area at $346.7 \mathrm{~m}^{2} / \mathrm{g}$, compared with $325.0 \mathrm{~m}^{2} / \mathrm{g}$ for the sample calcined at $210{ }^{\circ} \mathrm{C}$, but the sulfur pick-up capacity has little difference. This means that the surface area of the sorbent is not the only factor determining the sulfur pick-up capacity, given the same compositions of the samples; the activation may exert different effect on the component dispersion.

The decrease of the strength with the increase of the calcination temperature may be due to the decomposition of the starch binder. The increase of the surface area is due to the decomposition of the pore-making agent in the

Table 2 Changes of the surface area, strength, and sulfur capacity of $\mathrm{ZnCuO}_{x} / \mathrm{Al}_{2} \mathrm{O}_{3}-\mathrm{C}$ (with $50 \% \mathrm{C}$ in the support) with the activation temperature

\begin{tabular}{lrrrrr}
\hline Calcination temperature $/{ }^{\circ} \mathrm{C}$ & \multicolumn{1}{c}{120} & \multicolumn{1}{c}{150} & \multicolumn{1}{c}{180} & \multicolumn{1}{c}{210} & \multicolumn{1}{c}{240} \\
\hline Surface area $\left(\mathrm{m}^{2} / \mathrm{g}\right)$ & 152.1 & 179.6 & 267.8 & 325.0 & 346.7 \\
Side strength $(\mathrm{N} / \mathrm{cm})$ & 91.7 & 86.2 & 80.6 & 75.9 & 40.3 \\
Sulfur capacity $(\%)$ & 20.5 & 27.2 & 35.8 & 53.5 & 53.8 \\
\hline
\end{tabular}




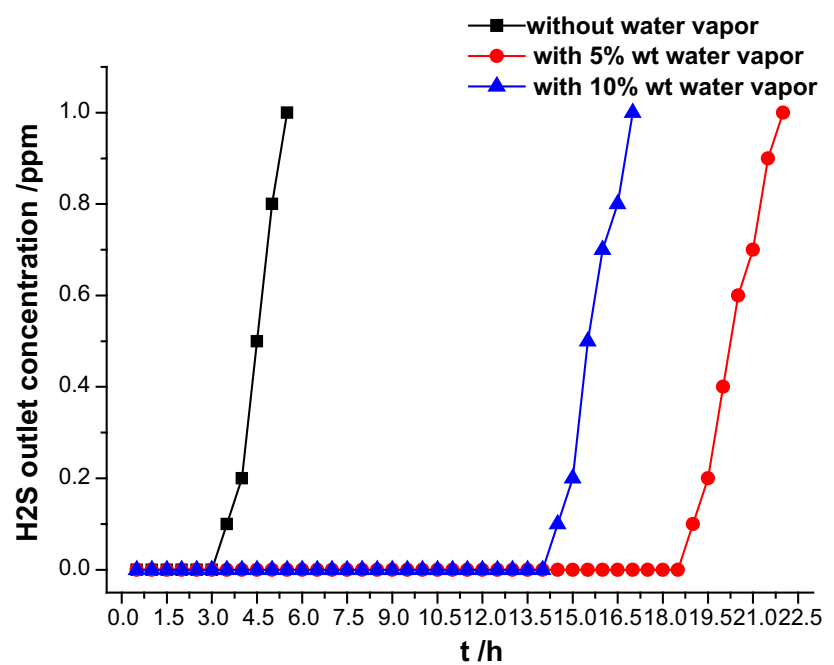

Fig. 3 Effect of steam on the $\mathrm{H}_{2} \mathrm{~S}$ removal efficiency of the $\mathrm{ZnCuO}_{x} /$ $\mathrm{Al}_{2} \mathrm{O}_{3}-\mathrm{C}(\mathrm{C}$ content $50 \%$ in the support $)$

extrudate like urea and citric acid, which can easily decompose at higher temperature and gives higher surface area.

\section{The effect of feed gas composition on the sulfur pick- up capacity}

The use of odour removal catalyst in indoor environment may be subject to many changes of the air composition, especially the humidity and the oxygen content. To explore the resistance of the catalyst to the changes of the humidity in air, we have tested the $\mathrm{ZnCuO}_{x} / \mathrm{Al}_{2} \mathrm{O}_{3}-50 \mathrm{wt} \% \mathrm{C}$ calcined at $210{ }^{\circ} \mathrm{C}$ for the air containing $0.5-10 \%$ of moisture in air, and the results are shown in Fig. 3. In the dry air containing no water vapour, the sulfur capacity is only $13.5 \mathrm{wt} \%$. However, when the air containing 5 vol\% water vapour, the sulfur capacity rapidly increases to $53.5 \%$, but when the moisture vapour increases to $10 \mathrm{vol} \%$, the sulfur capacity drops to $41.8 \mathrm{wt} \%$.

This is a very interesting phenomenon, as the absence of moisture may only lead to the $\mathrm{H}_{2} \mathrm{~S}$ to diffuse onto the sorbent surface slowly, as its content is much less than $\mathrm{O}_{2}$ and $\mathrm{N}_{2}$. However, when water vapour is present in the air, it has affinity to the alumina surface and thus may form a wet-surface, which can has higher solubility to $\mathrm{H}_{2} \mathrm{~S}$ and also promote the dissociation of $\mathrm{H}_{2} \mathrm{~S}$ over the catalyst surface. When the moisture content increases to $10 \mathrm{vol} \%$, which may compete with the absorption of $\mathrm{H}_{2} \mathrm{~S}$, thus hinder the $\mathrm{H}_{2} \mathrm{~S}$ absorption over the catalyst, thus having a lower sulfur capacity.

\section{The effect of oxygen content on the sulfur capacity}

The catalyst containing $50 \%$ carbon and calcined at $210{ }^{\circ} \mathrm{C}$ has been tested in $\mathrm{N}_{2}+\mathrm{H}_{2} \mathrm{O}, \mathrm{N}_{2}: \mathrm{O}_{2}: \mathrm{H}_{2} \mathrm{~S}=4: 1: 1$,

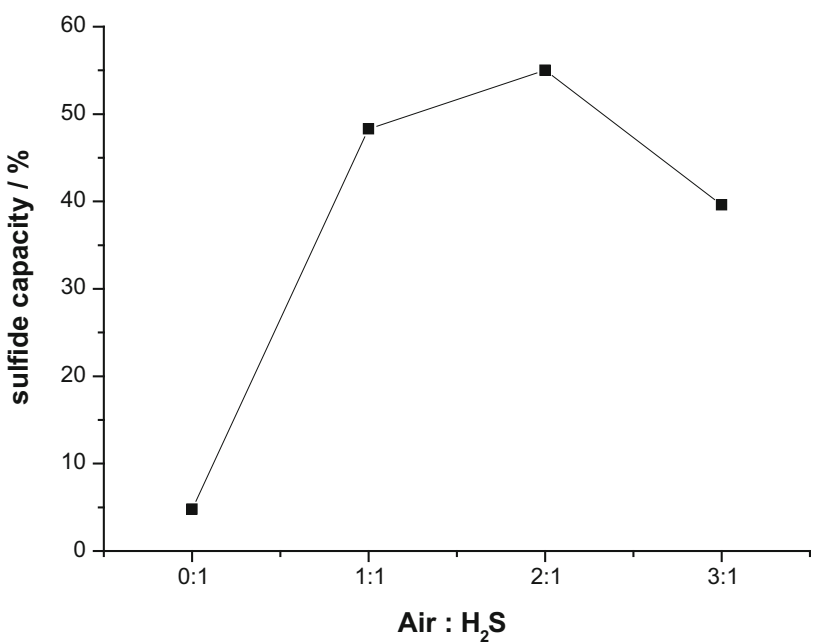

Fig. 4 Effect of $\mathrm{O}_{2}$ on the sulfur removal efficiency of the catalyst containing $50 \% \mathrm{C}$ and calcined at $210{ }^{\circ} \mathrm{C}$ with the presence of moisture in the inlet gas

$\mathrm{N}_{2}: \mathrm{O}_{2}: \mathrm{H}_{2} \mathrm{~S}=8: 2: 1$, and $\mathrm{N}_{2}: \mathrm{O}_{2}: \mathrm{H}_{2} \mathrm{~S}=12: 3: 1$ with all the gas stream containing $5 \mathrm{vol} \% \mathrm{H}_{2} \mathrm{O}$ (moisture). The test results are shown in Fig. 4. Interestingly, the absence of oxygen in the $\mathrm{N}_{2}$ gas stream gives only $4.8 \mathrm{wt} \%$, showing that the sulfur capacity of the catalyst is influenced by the gas composition significantly. However, when oxygen is introduced into the gas stream, the sulfur capacity increases sharply to nearly $50 \%$ and when the oxygen and nitrogen further increase while the $\mathrm{H}_{2} \mathrm{~S}$ content decreases, the sulfur capacity further increases, based on the exit $\mathrm{H}_{2} \mathrm{~S}$ content drop. This is quite unusual, as the lower $\mathrm{H}_{2} \mathrm{~S}$ in the feed would give lower sulfur capacity, however, the increase of oxygen does increase the sulfur capacity, with the most sulfur removal in the gas stream of $\mathrm{N}_{2}: \mathrm{O}_{2}: \mathrm{H}_{2} \mathrm{~S}=8: 2: 1$. When oxygen is further increased with less $\mathrm{H}_{2} \mathrm{~S}$ in the inlet gas stream, the sulfur removal efficiency drops with the catalyst sulfur capacity only $41 \mathrm{wt} \%$.

The above can be explained by the following assumption. Without oxygen, the $\mathrm{H}_{2} \mathrm{~S}$ is absorbed onto the $\mathrm{CuO}$ and $\mathrm{ZnO}$ which can be expressed as follows:

$\mathrm{H}_{2} \mathrm{~S}+\mathrm{CuO} \rightleftharpoons \mathrm{H}_{2} \mathrm{O}+\mathrm{CuS}$

$\mathrm{H}_{2} \mathrm{~S}+\mathrm{ZnO} \rightleftharpoons \mathrm{H}_{2} \mathrm{O}+\mathrm{ZnS}$.

When $\mathrm{O}_{2}$ is present in the gas stream, the sulfur can be converted into sulfur powder, which would regenerate the sulfide surface, the whole process can be expressed as follows:

$\mathrm{CuS}+1 / 2 \mathrm{O}_{2} \rightleftharpoons \mathrm{CuO}+\mathrm{S}$

$\mathrm{ZnS}+1 / 2 \mathrm{O}_{2} \rightleftharpoons \mathrm{ZnO}+\mathrm{S}$.

As no $\mathrm{SO}_{2}$ is detected in the exit gas, but the sulfur is significantly decreased in the exit gas, the sulfur would be accumulated over the catalyst surface. 
Table 3 Comprehensive test results of the various sulfur-containing air

\begin{tabular}{llll}
\hline $\begin{array}{l}\text { Odour } \\
\text { compounds }\end{array}$ & $\begin{array}{l}\text { Sulfur pick-up } \\
\text { capacity (wt\%) }\end{array}$ & $\begin{array}{l}\text { Removal } \\
\text { efficiency }(\%)\end{array}$ & $\begin{array}{l}\text { Time on stream } \\
\text { (h) }\end{array}$ \\
\hline $\mathrm{H}_{2} \mathrm{~S}$ & 44.61 & 99.9 & 120 \\
$\mathrm{CH}_{3} \mathrm{SH}$ & 9.87 & 99.8 & 120 \\
$\mathrm{CH}_{3} \mathrm{CH}_{2} \mathrm{SH}$ & 0.55 & 100 & 120 \\
$\mathrm{CH}_{3} \mathrm{SCH}_{3}$ & 0.82 & 66.9 & 120 \\
$\mathrm{C}_{2} \mathrm{H}_{5} \mathrm{SC}_{2} \mathrm{H}_{5}$ & 0.93 & 100 & 120 \\
$\mathrm{CH}_{3}-\mathrm{S}_{2}-\mathrm{CH}_{3}$ & 7.76 & 100 & 120 \\
In all & 64.54 & Average 93.34 & 120 \\
\hline
\end{tabular}

However, further increase of $\mathrm{O}_{2}$ could not increase sulfur capacity, as the dilution of $\mathrm{H}_{2} \mathrm{~S}$ and also the competitive absorption of other gas with $\mathrm{H}_{2} \mathrm{~S}$, in contrast this lowers the sulfur capacity a little bit.

\section{Comprehensive removal of odour compounds}

In the previous test, we focus on $\mathrm{H}_{2} \mathrm{~S}$, which is the predominant pollutant and most often present in air. However, organic sulfur-containing compounds often co-exist with $\mathrm{H}_{2} \mathrm{~S}$, although their concentration in one or two magnitude lower than $\mathrm{H}_{2} \mathrm{~S}$; therefore, we have made a gas mixture which contains ppm level of $\mathrm{H}_{2} \mathrm{~S}$ and ppb level of organic sulfur compounds, such as methyl mercaptan, ethyl mercaptan, methyl sulfide, ethyl sulfide, and dimethyl disulfide, the gas stream containing these sulfur compounds flows through the $\mathrm{ZnCuO}_{x} / \mathrm{Al}_{2} \mathrm{O}_{3}-\mathrm{C}$ catalyst under ambient conditions at GHSV of $2500 \mathrm{~h}^{-1}$, and the test results are shown in Table 3. It is interesting to find that the co-existence of the organic sulfur compounds, in fact, did not affect the performance of the catalyst for $\mathrm{H}_{2} \mathrm{~S}$ removal, in fact, the total sulfur capacity increase to $65.54 \mathrm{wt} \%$, and the sulfur removal ratios are mostly above $99.8 \%$ for the all the odour sulfur compounds except the dimethyl sulfide, which is light and may be difficult to absorb onto the catalyst. In the $120 \mathrm{~h}$ time on stream, the catalyst worked steadily and there was no any smell, as the methyl sulfide in the exit gas stream was only $1 \mathrm{ppb}$.

Catalyst test conditions: ambient temperature, atmosphere pressure, and the space velocity of sulfur-containing compounds $\mathrm{N}_{2}$ flowing gas: $2500 \mathrm{H}^{-1}$; the sulfur compounds content is from $100 \mathrm{ppb}$ to $10 \mathrm{ppm}$; and the catalyst is considered as breakthrough when sulfur in the outlet stream is about $1 \mathrm{ppb}$.

From Table 3, it is clearly shown that the $\mathrm{ZnCuO}_{x}$ I $\left(\mathrm{Al}_{2} \mathrm{O}_{3}-\mathrm{C}\right)$ catalyst effectively removes not only $\mathrm{H}_{2} \mathrm{~S}$, but also the organic sulfur compounds.

\section{Application of the self-regenerable catalyst}

An odour removal blanket has been fabricated using our ambient temperature self-regenerable catalyst, which was loaded over water proof, but gas breathable cloth, as shown in Fig. 5. This blanket was placed into a waste water passes through area, where a vent is needed to prevent the potential explosion, the square blanket was just placed over vent held by a screen gate, and the air quality was monitored daily for 1 year. We can see that the $\mathrm{H}_{2} \mathrm{~S}$ was reduced to $0 \mathrm{ppm}$ from 3 to $20 \mathrm{ppm}$. Moreover, $\mathrm{CO}$ content was also reduced to 0 from 15 to $20 \mathrm{ppm}$ before the blanket was placed. After 9 month operation, no odour was detected, and even, no $\mathrm{CO}$ was detected. However, after 6 month operation, we found that very fine yellow powder gradually appeared in the blanket surface, which is sulfur powder. The process can be expressed by the following reaction:

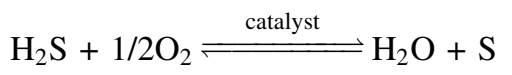

As we did not detect the presence of $\mathrm{SO}_{2}$, the sulfur powder generated over the catalyst is confidently assigned to the conversion of $\mathrm{H}_{2} \mathrm{~S}$.
Fig. 5 Images of the de-odour blanket containing sulfur conversion $\mathrm{ZnCu}-\mathrm{Al}_{2} \mathrm{O}_{3} \mathrm{C}$ catalysts: a before use, $\mathbf{b}$ after a half-year on-site use
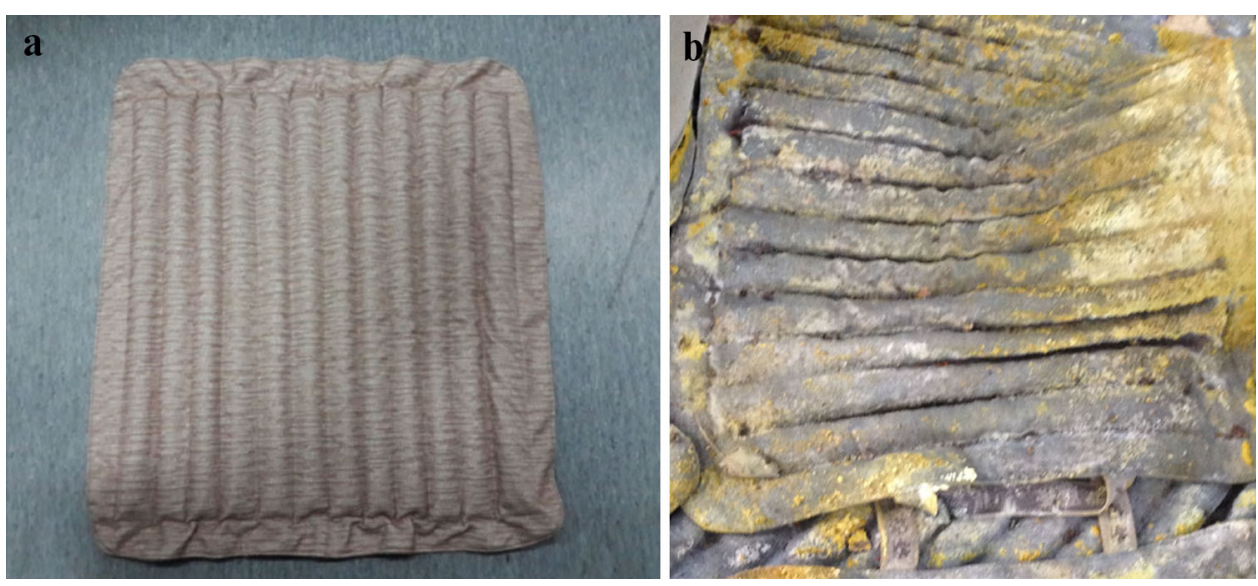
$\mathrm{O}_{2}$ is from the air around, and also, we also placed an active carbon blanket for reference, which has a little effect in removal the odour, and CO content is almost unchanged in another vent area.

Table 4 shows the changes of the changes of $\mathrm{H}_{2} \mathrm{~S}$ and $\mathrm{CO}$ after installing the $\mathrm{ZnCuO}_{x} / \mathrm{Al}_{2} \mathrm{O}_{3}-\mathrm{C}$ containing blanket in the Qinghe Sewerage Plant, Beijing; the data were obtained using an on-site sensor, and also verified by the person working on site. Before the blanket was installed on site, it was very smelly and also the worker on-site felt sick,

Table 4 On-site record of the results after placing the sulfur converting catalyst $\mathrm{ZnCu} / \mathrm{Al}_{2} \mathrm{O}_{3} \mathrm{C}$ (50\% of $\mathrm{C}$ in the support) in Beijing Qinghe Sewerage Plant

\begin{tabular}{llllll}
\hline Date & Time & $\begin{array}{l}\mathrm{H}_{2} \mathrm{~S} \\
\text { ppm }\end{array}$ & $\begin{array}{l}\mathrm{CO} \\
\text { ppm }\end{array}$ & $\begin{array}{l}\mathrm{O}_{2} \\
\text { vol\% }\end{array}$ & Remark \\
\hline 12-May-14 & $11: 00$ & 4 & 15 & 21 & $\begin{array}{c}\text { No odour removal } \\
\text { catalyst used }\end{array}$ \\
& $15: 00$ & 2 & 18 & 21 & After the sulfur \\
13-May-14 & $9: 00$ & 0 & 0 & 21 & conversion \\
& $11: 00$ & 0 & 0 & 21 & catalyst blanket \\
& $15: 00$ & 0 & 0 & 21 & is used \\
15-Jul-14 & $9: 00$ & 0 & 0 & 21 & \\
& $11: 00$ & 0 & 0 & 21 & \\
& $15: 00$ & 0 & 0 & 21 & \\
14-Sep-14 & $9: 00$ & 0 & 0 & 21 & \\
& $11: 00$ & 0 & 2 & 21 & \\
& $15: 00$ & 0 & 1 & 21 & \\
16-Oct-14 & $9: 00$ & 0 & 0 & 21 & \\
& $11: 00$ & 0 & 0 & 21 & \\
& $15: 00$ & 0 & 1 & 21 & \\
14-Nov-14 & $9: 00$ & 0 & 0 & 21 & \\
& $11: 00$ & 0 & 1 & 21 & \\
& $15: 00$ & 0 & 0 & 21 & \\
\hline
\end{tabular}

Fig. 6 XRD patterns of the $\mathrm{ZnCuAl}_{2} \mathrm{O}_{3}-\mathrm{C}$ catalyst: a before and $\mathbf{b}$ after half-year use in a sewerage water treatment plant as there was $\mathrm{CO}$ also generated. After installing the odour removal blanket, from 12th May 2014 to 14th Nov 2014, no smell was felt, and the onsite sensor shows that $\mathrm{H}_{2} \mathrm{~S}$ was reduced to 0 , and $\mathrm{CO}$ was also reduced, while oxygen concentration almost un-changes. This further supports the catalytic effect of the $\mathrm{ZnCuO}_{x} / \mathrm{Al}_{2} \mathrm{O}_{3}-\mathrm{C}$ which can chemically convert $\mathrm{H}_{2} \mathrm{~S}$ into yellow sulfur powder, as shown in Fig. 5. The removal of $\mathrm{CO}$ over the $\mathrm{ZnCuO}_{x} / \mathrm{Al}_{2} \mathrm{O}_{3}-\mathrm{C}$ makes the working environment safer.

\section{Characterization of the prepared sulfur sorbents}

The sulfur removal catalyst containing $50 \%$ of active carbon in the support was measured using XRD, and the results are shown in Fig. 6 . The diffraction peaks at about $25^{\circ}$ of $2 \theta$ are assigned to the graphite peaks. The diffraction peaks at 32 and $34^{\circ}$ are due to the $\mathrm{CuO}$ and the peak at $42^{\circ}$ is due to $\mathrm{Cu}_{2} \mathrm{O}$. The peak at $37^{\circ}$ is due to $\mathrm{ZnO}$. After the sulfur removal catalyst is used in open air for more than a half year, while the catalyst is still active, its XRD pattern showed almost the same diffraction as the fresh one, although there is some amount of sulfur in the blanket. This suggests that the catalyst has self-regenerate capability; it keeps the oxide as the active phase, the sulfur is converted into sulfur powder. This is in agreement with the on-site application results.

The SEM and TEM of the odour removal catalyst containing $50 \%$ of active carbon in the support are shown in Fig. 7. It is clearly seen that the fresh catalyst composes of 300-500 nm metal oxide particles, which are uniformly distributed in the catalyst. It has lots of square crystal particles which are in the range of 300-500 nm, no carbon or other isolated particles are seen, which suggests that the preparation method gives a uniform phases of the various

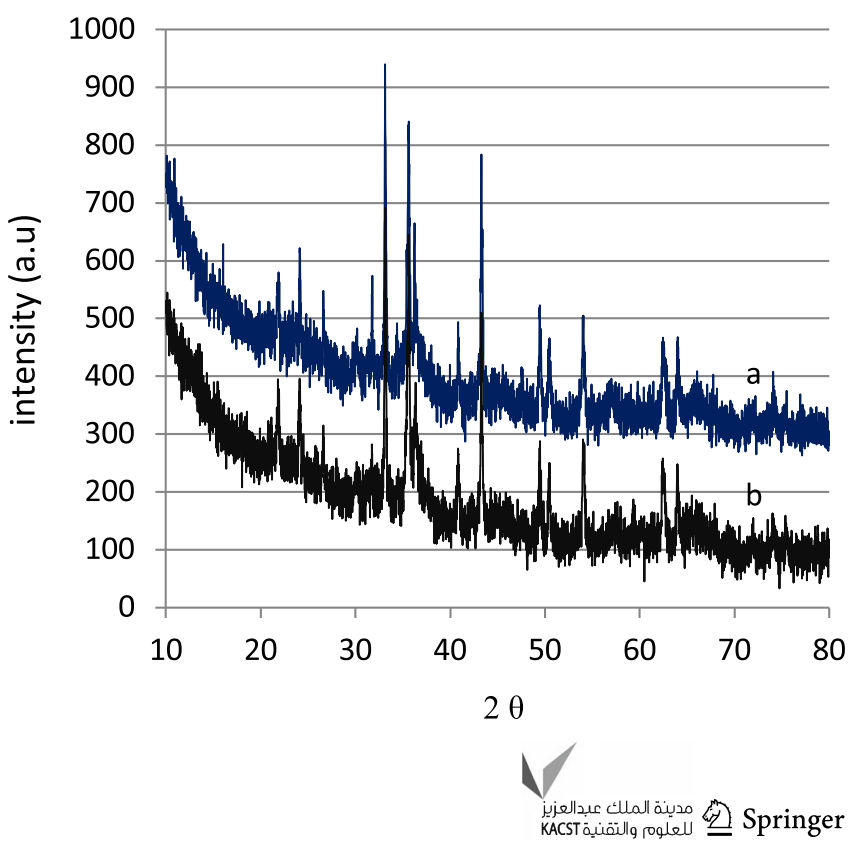


Fig. 7 Images of the electron microscope of the $\mathrm{ZnCuO}_{x}$ I $\mathrm{Al}_{2} \mathrm{O}_{3}-\mathrm{C}$ catalyst with $50 \%$ of carbon, a SEM of the fresh catalyst, $\mathbf{b}$ the catalyst after half-year use, $\mathbf{c}$ the TEM images of the fresh catalyst, and $\mathbf{d}$ the TEM images of the used $\mathrm{ZnCuO}_{x} / \mathrm{Al}_{2} \mathrm{O}_{3}-\mathrm{C}$ catalyst after half-year on-site use
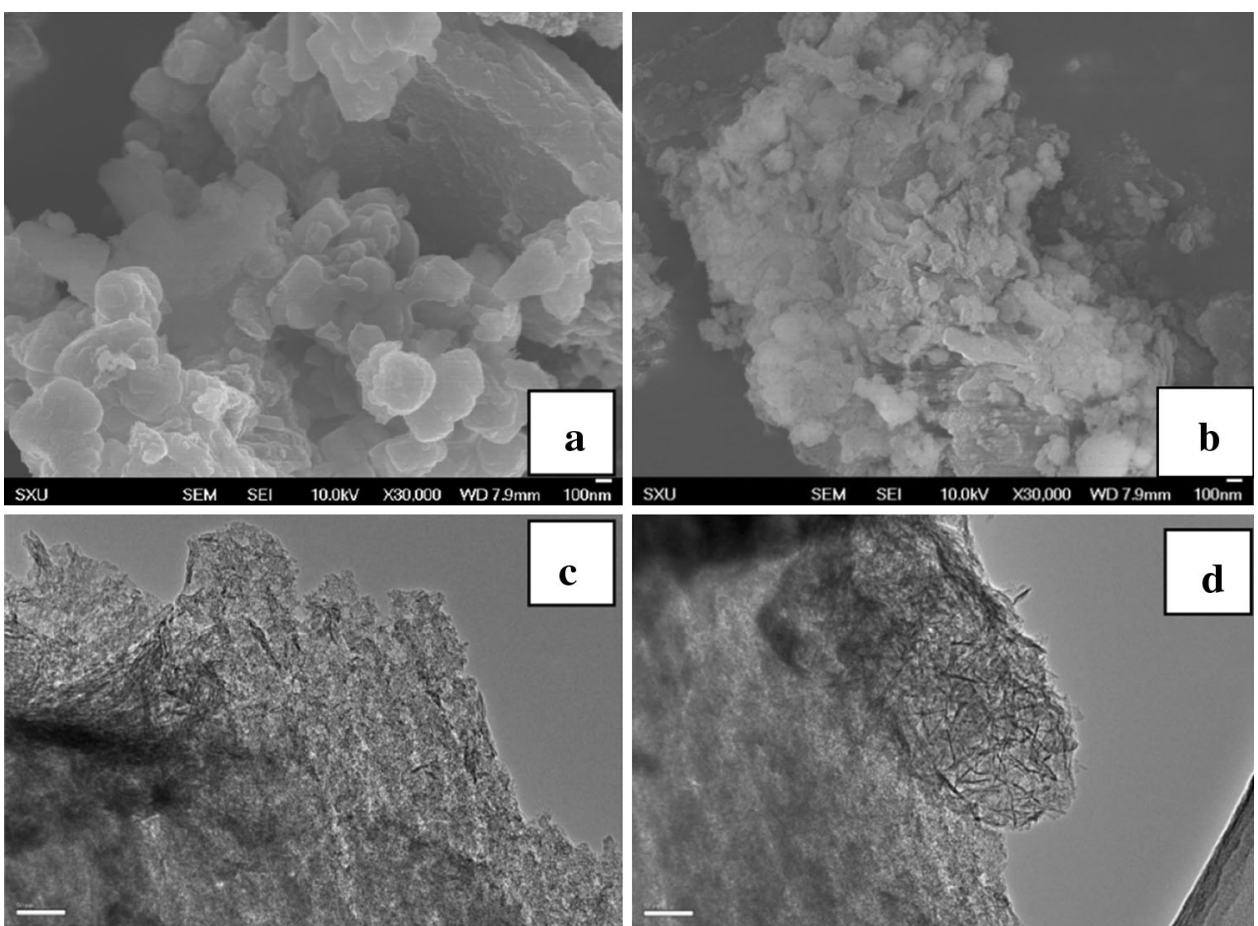

components, as the preparation is wet method, which can make the active components evenly soaked to the supports. After the sorbent is used for more than a half year, the micro-structure changes, it tends to become smaller, which may be induced by the moisture, $\mathrm{CO}_{2}$, and sulfur in the air atmosphere. However, as shown in Fig. 6, the main diffraction peaks do not have any major changes, e.g., the crystalline structure remains unchanged. Thus, we believe that the smaller particles and irregular morphologies were just the changes of the surface.

A further detailed observation of the $\mathrm{ZnCuO}_{x} / \mathrm{Al}_{2} \mathrm{O}_{3}-\mathrm{C}$ catalyst was carried out using a transmission microscope, and the images of the fresh and used catalyst are shown in Fig. $7 \mathrm{c}$ and d. It is seen that the active carbon is mixed well with the active components and alumina support, even after the half-year application, no significant changes occurred over the catalyst, which further supports that the changes in the SEM results after use only happen over the catalyst surface. No sulfide phases or sulfates are detected, which suggests that the sulfur is mainly sulfur powder as seen in Fig. 5, the yellow powder.

\section{Conclusion}

We have developed a novel formulation of odour removal catalyst which has self-regenerability, and can convert the sulfur-containing odour compounds into sulfur powder in the presence of oxygen, which is from air.
The catalysts compose of $\mathrm{Cu}$ and $\mathrm{Zn}$, and the support is a comprehensive composite of $\mathrm{Al}_{2} \mathrm{O}_{3}$ and active carbon. The optimal condition for the preparation is calcination at $210{ }^{\circ} \mathrm{C}$ in the presence of moisture containing flowing air.

The catalysts have been tested for various sulfur-containing gas streams, which show high sulfur capacity and self-regeneration capability, especially when applying to the real environment for surface pollutant control. It converts $\mathrm{H}_{2} \mathrm{~S}$ and thiophene into sulfur powder, and also converts $\mathrm{CO}$ into $\mathrm{CO}_{2}$ with very stable performance.

No structural changes occurred in the sorbent after halfyear use in the sewerage plant, where the odour was removed and the sulfur is converted into sulfur powder, and due to the oxygen in the air, the $\mathrm{Cu}$ and $\mathrm{Zn}$ are still present in their oxide form.

Acknowledgments We would like to thank Professor Helen Lou from Lamar University for her advice and constructive comments. This project was financially supported by the Guangzhou Municipal Government Challenge Project (Project No. 2014J4500003).

Open Access This article is distributed under the terms of the Creative Commons Attribution 4.0 International License (http:// creativecommons.org/licenses/by/4.0/), which permits unrestricted use, distribution, and reproduction in any medium, provided you give appropriate credit to the original author(s) and the source, provide a link to the Creative Commons license, and indicate if changes were made. 


\section{References}

1. Koe LCC (1988) Characterization and removal of odors from refuse material. Environ Monit Assess 10(1):75-84

2. Filipy $\mathbf{J}$ et al (2006) Identification and quantification of volatile organic compounds from a dairy. Atmos Environ 40(8):1480-1494

3. Le Leuch LM, Subrenat A, Le Cloirec P (2004) Removal of target odorous molecules on to activated carbon cloths. Water Sci Technol 50(4, Odours and Volatile Organic Compounds II): $193-198$

4. Lillo-Rodenas MA et al (2008) Further insights into the activation process of sewage sludge-based precursors by alkaline hydroxides. Chem Eng J 142(2):168-174

5. Muezzinoglu A (2003) A study of volatile organic sulfur emissions causing urban odors. Chemosphere 51(4):245-252

6. Vega $\mathrm{E}$ et al (2011) Air quality assessment in a highly industrialized area of Mexico: concentrations and sources of volatile organic compounds. Fuel 90(12):3509-3520

7. Chen $\mathrm{G}$ et al (2014) Fiber adsorbents for odorant removal from pipeline grade natural gas. Ind Eng Chem Res 53(17):7113-7120

8. Cui H, Turn SQ, Reese MA (2009) Removal of sulfur compounds from utility pipelined synthetic natural gas using modified activated carbons. Catal Today 139(4):274-279

9. Gabriel D, Deshusses MA (2003) Performance of a full-scale biotrickling filter treating $\mathrm{H}_{2} \mathrm{~S}$ at a gas contact time of 1.6 to 2.2 seconds. Environ Prog 22(2):111-118

10. Kang S-H et al (2007) Effective removal of odorants in gaseous fuel for the hydrogen station using hydrodesulfurization and adsorption. Energy Fuel 21(6):3537-3540

11. Turk A et al (1989) Ammonia injection enhances capacity of activated carbon for hydrogen sulfide and methyl mercaptan. Environ Sci Technol 23(10):1242-1245
12. Kim H-T et al (2007) Desulfurization of odorant-containing gases by sorption on $\mathrm{Cu} / \mathrm{ZnO} / \mathrm{Al}_{2} \mathrm{O}_{3}$ : effects of sulfur compounds. Energy Fuel 21(1):327-332

13. Arpacioglu B, Allen ER (1996) Control of organo-sulfur compound emissions using biofiltration: dimethyl disulfide. Proc Annu Meet Air Waste Manage Assoc 89:rp87c02/1-rp87c02/16

14. Huang C-Y et al (2011) Probing the adsorption characteristic of metal-organic framework MIL-101 for volatile organic compounds by quartz crystal microbalance. Environ Sci Technol 45(10):4490-4496

15. Khan NA, Hasan Z, Jhung SH (2013) Adsorptive removal of hazardous materials using metal-organic frameworks (MOFs): a review. J Hazard Mater 244-245:444-456

16. Kim H-T et al (2006) Co-precipitated $\mathrm{Cu} / \mathrm{ZnO} / \mathrm{Al} 2 \mathrm{O} 3$ sorbent for removal of odorants t-butylmercaptan (TBM) and tetrahydrothiophene (THT) from natural gas. Energy Fuel 20(5):2170-2173

17. Ziolek $M$ et al (2008) Nanosorbents for selective removal of odours. Mater Sci Pol 26(2):425-431

18. Brodu N et al (2012) Removal of volatile organic compounds by heterogeneous ozonation on microporous synthetic alumina silicate. Water Sci Technol 66(9):2020-2026

19. Zeng D et al (2015) Effect of surface properties of iron oxide sorbents on hydrogen sulfide removal from odor. Clean Soil Air Water 43(7):975-979

20. Xiao $\mathrm{T}$ et al (2013) Deodorant and preparation method and application thereof. Guangzhou Boxenergy Technology Co., Ltd., People's Republic of China, $\mathrm{p} 9$

21. Xiao T, Moreau P, Zhao Y (2008) Preparation of super active cobalt based hydrogenation catalysts. Prepr Symp Am Chem Soc Div Fuel Chem 53(1):166-167 